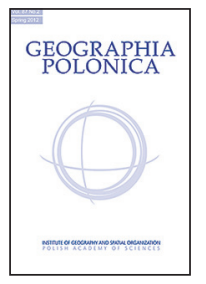 \\ INSTITUTE OF GEOGRAPHY AND SPATIAL ORGANIZATION \\ POLISH ACADEMY OF SCIENCES \\ www.igipz.pan.pl \\ www.geographiapolonica.pl
}

\title{
MOBILITY AND REGIONALISATION: CHANGING PATTERNS OF AIR TRAFFIC IN THE BALTIC SEA REGION IN CONNECTION TO EUROPEAN INTEGRATION
}

\author{
Jan Henrik Nilsson \\ Department of Service Management and Service Studies \\ Lund University \\ Box 882, 25108 Helsingborg: Sweden \\ e-mail: jan-henrik.nilsson@ism.lu.se
}

\begin{abstract}
The geo-political transition in 1989-91 had long term consequences for the European integration process. The integration and regionalisation processes following the transition resulted in a transformation of territorial borders in and around the region; the functions of the borders changed. Mobility is vital for these processes. This paper is based on a longitudinal study of the development of air traffic from airports in the eastern part of the Baltic Sea Region, 2000-2012. The purpose of the paper is to discuss how the development of infrastructure and transport networks influence regionalisation processes in the Baltic Sea Region. Firstly, the impact of macro-economic development as a driver of internationalisation in the region is analysed, thereafter the relationship between institutional transition and regional system development. There are three periods of large increase in traffic from the Baltic States towards Western Europe, related to institutional change: rapidly after independence, as a result of the enlargement of the European Union, and related to the emergence of low-cost aviation. Aviation from Minsk and Kaliningrad have also shown substantial increase in air traffic, but mainly to other parts of the former Soviet Union. There is thus little evidence of a regionalisation process involving the whole region.
\end{abstract}

\section{Key words}

Geo-political change $\bullet$ borders $\bullet$ mobility $\bullet$ aviation $\bullet$ the Baltic Sea Region

\section{Introduction}

In the Baltic Sea Region, the geo-political transition of 1989-91 had almost revolutionary consequences. The monolithic political system in the Soviet Union and Central Europe fell apart; the former socialist states developed their own forms of government. As the Cold War came to an end, the Warsaw Pact ceased to exist and Russian troops gradually left their postings in Central Europe and the Baltic States. For the first time since World War Two the political map of Europe was transformed (Lieven 1994; Gerner \& Karlsson 2002; 
North 2011). As a consequence of geo-political transition the former 'Eastern' Europe went through a process of dis-integration. In this process, a series of strong networks within the former socialist Eastern Europe were broken up when new barriers were created. Trade within the former SEV (Comecon) decreased significantly (Nove 1992; Nilsson 2000; Paldam 2002). Old and established industrial networks broke down, within countries and between the previous socialist countries (Andreff \& Andreff 1995; Shaw 1999). The long term effects of this dis-integration process are still difficult to estimate.

The new geo-political situation, in particular the regained independence of the Baltic States, became a starting point for a period of intense co-operation across the Baltic Sea. Already in the mid 1990 's the number of initiatives, programmes and organisations promoting Baltic Sea co-operation could be counted in the hundreds (Stålvant 1996). The inclusion of Finland and Sweden into the European Union in 1995 'created operational frameworks for this co-operation and changed again the role of borders' (Jauhiainen 2000: 103). These processes could be understood in terms of regionalization. We witnessed an increase in the density of communications across the former east-west divide, and intense development of regional organisations and institutions. However, it could be argued that the 'the new Hanseatic League' is to be viewed more as a formation of networks than as an example of territorial region building - just like the old one.

The integration process in the Baltic Sea Region has inevitably had material consequences; interaction (flows of goods, people, capital and messages) is transformed along with territorial restructuring. Travel and trade between the different parts of the Baltic Sea Region multiplied in the 1990 's. For example, trans-border travel increased very fast in the early 1990 's, mainly as a result of liberalized passport and visa regulations, and small scale trade taking advantage of differences in prices and supply of consumers' goods (Brodin 2000; Kisiel-Łowczyc 2000; Nilsson 2003;
Komornicki \& Miszczuk 2010). However, since the early 2000's tendencies of re-bordering have become visible. The enlargement of the European Union in 2004, and the subsequent extension of the Schengen zone in 2007, resulted in a decrease in traffic over Europe's new cordon sanitaire. For example, ground traffic between Poland and its eastern neighbours Russia, Belarus and the Ukraine went down considerable (more than 50\%) between 2006 and 2008 (Komornicki 2010). The process of simultaneous de-bordering and re-bordering has become very complex, especially in relation to the Western parts of the former Soviet Union. Different forms of mobility are a vital ingredient in these processes, both as a driving force for change and as an outcome of geopolitical processes, thus determining the character of functional integration.

The geo-political situation at the borders of the 'new' Europe has raised considerable scientific interest. This has to a large extent been focused on geo-political topics, mainly the role of the $\mathrm{EU}$ in the enlargement process (e.g. Bialasiewicz et al. 2009; Scott 2009b; Bialasiewicz 2011). There has also been an interest in the role of cross-border region building (Scott 2006; Kramsch 2003; Lepik 2009), much of the research has however targeted limited geographical regions (e.g. Krätke 1998; Lundén \& Zalamans 2001; Joenniemi \& Sergunin 2011; Schönweitz 2015) or specific subject areas such as tourism (e.g. loannides et al. 2006; Nilsson et al. 2010; Timothy \& Saarinen 2013; Timothy et al. 2016; Więckowski \& Cerić 2016). With the exception of migration (Parker \& Vaughan-Williams 2012; Kahila et al. 2013) the role of mobility is to a large degree neglected, or taken for granted. In connection to the integration process in the Baltic Sea Region, transports and infrastructure have with few exceptions (Nilsson, 2015) mainly been discussed in policy related reports (VASAB 1994; Böhme et al. 1998; Schmitt \& Dubois 2008). Aviation is only sparsely mentioned in the literature, it mostly deals with particular carriers or with the development at single airports. For instance, Christauskas and Stanaitis (2008) describes traffic 
development at Tallinn, Riga, Vilnius, and Krakow airports. Only a few scientific texts discuss the development of aviation in the Baltic Sea Region from a systematic regional perspective (Nilsson 2003; Wichmann-Mathiessen 2004). These texts describe the period after the fall of the Iron Curtain but prior to the EU enlargement. There is thus a need for new research in this particular field, not the least in relation to current theory in political geography.

In order to contribute to a discussion on the impact of mobility on regionalisation and bordering processes, the purpose of the present paper is to describe and analyse the relationship between the development of international aviation and regionalisation processes in the Baltic Sea Region. This is done with the help of a longitudinal study describing the development of air traffic from a selection of airports in the eastern part of the Baltic Sea Region in a long term perspective. Such a study has not been done before in this context. The paper will add to the general understanding of the integration process in the Baltic Sea Region.

The outline of the paper will be as follows: the next section presents the theoretical framework of the paper. The third section presents the empirical material and the methodology used for the study. Thereafter the empirical results are presented and analysed, followed by a concluding discussion.

\section{Territories, borders, and mobility}

Territorial states, as sovereign and stable historical constructions, reached their peak in the 20th century (Elden 2011). The post-war United Nations system was essentially built on Westphalian principles. In addition, most industrialised countries were building welfare states strongly promoting internal integration; the 'infrastructural power of the state' (Mann 1993) grew very strong. Infrastructure could in this context be viewed both as government, social and cultural institutions (Deutsch 1953) and as the material structures physically integrating the state's territory. During the latest decades, the supremacy of the territorial state has been challenged following economic restructuring, globalisation, and geo-political transformation. These processes might be described in terms of de-territorialisation ( $\mathrm{O}$ 'Tuathail 1998). By this, O 'Tuathail does not mean that the territorial states are about to disappear; instead they are "changing status, power and meaning in relationship to postmodern technological constellations, speed machines and global webs of capitalism" (ibid: 82). In other words, structural processes such as globalisation and time-space compression challenge the territorial state from above.

Territorial states are also challenged from below. Building on older regional territorial constructions and identities, a number of European countries have since the 1970's given increased authority to regional political bodies. Regionalisation processes in Europe have gone hand in hand with the integration process in the European Union (Jönsson et al. 2000). Most often the term regionalisation process refers to processes within territorial states. However, there are increasing efforts by the EU to promote regionalisation in other contexts as well, as cross-border regions or in the form of macro-regional cooperation (Grix \& Knowles 2002; Scott 2002; Kramsch 2003; Scott 2006; Scott 2009a). Regions should in this context be viewed as historical constructions, often based on continuities of space and identity; but continuously re-constructed along with geopolitical transformations.

In a seminal paper, Anssi Paasi (1986: 121, original emphasis) describes the historical development of regions by distinguishing "four [interacting] stages in the process of institutionalization of a region: 1) assumption of territorial shape, 2) development of conceptual (symbolic) shape, 3) development of institutions, and 4) establishment as part of the regional system and regional consciousness of the society concerned". Paasi's model clearly aims at analysing the emergence of regional identities, and it is based on studies of regionalisation processes within territorial states. Despite this, his line of reasoning is a fruitful point of departure for discussing cross-border regionalisation as well. 
In the Baltic Sea Region, geographers have attempted to construct and delimit the territorial shape of the region for at least a century (De Geer 1928; Kant 1935a,b). In the inter-war period, following the independence of Finland and the Baltic States, the conceptualisation of the Baltic Sea Region became part of a political project aimed at building links between the Baltic States and the Nordic countries (Kant 1935a,b). Despite these emerging 'representations of space' (Lefebvre 1991) there was not any institutional framework initiated in the Baltic Sea Region, nor were there any significant signs of a cross-border regional consciousness. The institutionalisation processes of the respective nation states were prioritised. During an instable period of time, issues related to territories and borders were in the forefront in regionalisation processes that were mainly national in scope.

Being essentially territorial, processes of regionalisation will inevitably be constituted by demarcations and delimitations; regions are assuming their territorial shape (Paasi 1986). Thereby, "Territoriality [...] necessarily produces and focuses attention on borders" (Anderson \& O'Dowd 1999: 598). As borders are one of the central concepts in political geography, the functions and meanings of borders have been widely analysed. In most cases, the history of border studies is described as a process where new theoretical influences were continuously added to previous perspectives. Early political geography had nations and nation states as its defining object of study (Ratzel 1923). Borders were viewed as outcomes of struggles between nations, in which factors related to physical geography (topography, natural resources, etc.) were important parts of the analysis; hence the concept of 'natural borders' (Kjellén 1899). In economic geography, borders have traditionally been seen as the outer limits of national market areas, and as important barriers to trade and other cross border interaction (Lösch 1954). The common denominators of these two perspectives are that the territorial states, and their sovereignty within fixed borders, are taken for granted as the starting points for analysis, and that borders are 'physical realities' on the ground and on the map with measurable impact on interaction.

During the latest decades, critical and postmodern perspectives reflecting current developments in social science have influenced border studies. According to these perspectives, borders are essentially to be viewed as socially constructed. They are representations of power relations, and as such open to continuous renegotiation. Inspired by hermeneutics, the meanings of borders, the narratives associated with them, and the identities they are reflecting have come to the forefront in analysis (Paasi 1996; van Houtum 2000; van Houtum \& Strüver 2002; Agnew 2008). Regionalisation processes and cross border infrastructure projects are for example not only studied from functional perspectives; they are also objects of discourse analysis in order to come to terms with the political and ideological contexts in which they are embedded (Jensen \& Robinson 2004). Borders are not only regarded as state territorial constructions or barriers to interaction, they are also representations of vital geo-political discourses on different geographical levels and in different contexts.

As a consequence of this shift in perspectives, focus has moved to discussing borders as processes (Brunet-Jailly 2011). Therefore, historical analysis of border constructions is increasingly seen as important for understanding bordering processes (Paasi 1996). These processes are no longer only related to the physical border (Agnew 2008; Balibar 2009; Brunet-Jailly 2011; Novak 2011). Instead, there is an analytical ambition to "de-centre the border" (Parker \& Vaughan-Williams 2012: 728); borders 'take place' far outside their physical representations on the ground. For example: airports situated far from borders are in many cases the most frequently used border crossing points; visa processes may start at embassies long before any travel has begun; in logistics, clearances of goods virtually take place on the move. These examples show the relevance of current scientific emphasis on bordering practices and the performance of borders. It is also evident how important different 
aspects of mobility are for our understanding of the functional aspects of territorialities and bordering processes. Emphasising mobility brings in a necessary dynamic element in the analysis of territorial change. Physical mobility, for instance in the forms of improved transports and communications, may in itself course changes of territorial formations in the same way as changing bordering processes may impact trans-border mobility. This means that mobility is to be seen as a necessary part of regionalisation processes.

This leads us back to the third stage in Paasi's (1986) process of regional institutionalization, the formation of institutions. In analysing the development of regional institutions, Paasi (1986) concentrates on the political and cultural perspectives, in which he emphasizes the communicational aspects of regional institutionalisation. In addition, he discusses the importance of economic restructuring, i.e. structural change in the division of labour for the historical construction of regions. He also mentions the spheres of production, consumption and exchange as vital for the formation of market areas, and of regions as functional units. Apart from these relatively short statements, issues related to infrastructure, transports, and mobility seem to be taken for granted. There is obviously room to develop the discussion on Paasi's third stage, not least in relation to cross-border regionalisation.

First we need to look at how institutions are conceptualised. Institutions might simply be understood as the formal and informal rules of a society, its laws and conventions (North 1997). They could also be seen as the social organisations supporting these rules, as well as the material structures which are necessary prerequisites for their development. Looked upon this way, it seems obvious that the development of new institutional circumstances, or the destruction of old ones, may act as driving forces in regionalisation processes. More concretely, they affect those interactions which in fact are the 'materialisations of regionalisation' by changing the conditions for exchange, communication and travel. Travel may in this context be the most interesting form of mobility since personal contacts help to create and shape other interaction; travel might be viewed as an embodiment of international and interregional network formations (Sassen 2001; Taylor 2004; Derudder \& Witlox 2008). In a broader perspective international travel is thus both an outcome of globalisation and in itself a significant carrier of globalisation.

In contemporary international relations, flying stands out as the most significant form of travel. The flexible character of aviation allows it to adapt to changes in the environment faster than other forms of travel. The speed of aviation and the current dense networks allow for very high levels of interaction. Thus, changing patterns of aero-mobility are likely to reflect current processes of de-bordering and re-bordering. The study of travel patterns becomes a way of revealing functional aspects of territorial change. Describing change in mobility pattern, i.e. the material side of territorial change, thus becomes a way of operationalising geo-political restructuring. Understanding the development of infrastructure and interaction may also be a way of understanding the development of regional systems, thus relevant for understanding the first part of the fourth stage in Paasi 's model. (The latter part, the development of regional consciousness will not be analysed in this paper.)

\section{Method}

Following the reasoning above, it seems relevant to describe and analyse various aspects of the development of aviation in order to improve our understanding of the regionalisation process in the Baltic Sea Region. However, it needs to be stressed that studying aviation is only one of many possible ways of approaching the functional aspects of regionalisation in the region. To make the picture complete aspects like trade, investments, ground and sea traffic, flows of tourism, and other forms of mobility ought to be taken into account. This thematic limitation needs to be clarified. 
In the limited scope of this paper it is also necessary to make a geographical limitation. This study will concentrate on the development of aviation in the eastern part of the Baltic Sea Region, i.e. Estonia, Latvia, Lithuania, The Kaliningrad exclave, and Belarus. This is a fairly limited geographical area but with large contrasts within it. The three Baltic States have undergone a very dynamic development process and become integrated parts of the European political and economic systems. Belarus, on the other hand, has made little progress in connecting to Western Europe politically and economically. The Kaliningrad region faces a very special situation, separated from mainland Russia by land. Their respective patterns of interaction are thus likely to reflect different aspects of territorial change in the Baltic Sea Region. This limitation means that important parts of the Baltic Sea Region are missing: the Nordic countries, Germany, Poland and the St Petersburg region. In this study, the smaller and less studied parts of the region are thus in focus.

There are a number of problems connected to statistics of the flows of aviation, i.e. of the number of passengers travelling along different routes (see Nilsson 2003, for explanations). This calls for alternative methods of estimating passenger flows, such as using data from timetables. An alternative to using timetable data for mapping flows of air traffic would be to use data from major global distribution systems (Derudder et al. 2010; cf. Derudder et al. 2009). The problem with GDS material is however that a large part of the tickets for low-cost carriers is sold without using GDS; making such material impossible to use in the present study.

Every month, OAG World Airways Guide publishes a collection of the timetables for the World's scheduled flights. The present study area includes OAG timetable data from airports in the eastern part of the Baltic Sea Region. In practice, this means that the empirical material presented below is based on the air traffic from the following airports: Tallinn, Riga, Vilnius, Kaunas, Klaipeda (Palanga), Kaliningrad and Minsk. The study period starts in October 2000 and goes on until October 2012, thus including 13 similar measure periods. Week 42, around October 20th, was chosen because there are no public holidays, and traffic is close to the annual average. The timetables are organized based on the week; the connections normally follow the rhythm of the working week. With the help of timetable data, it is possible to estimate the number of direct connections from a certain city and the frequencies of these connections. It is also possible to estimate the available seat capacity (ASC), i.e. the number of seats flown on each connection. This number could also be termed the potential passenger flow, the total number of passenger in case all seats on all flights are occupied. In order to estimate the ASC you need to have information about the number of flights, the type of aircraft used and about the airline. (For example: Air Baltic made four flights between Riga and Gothenburg during week 42, 2010; using a Focker 50 with room for 46 passengers. ASC for this connection was thus 184 passengers a week.) ASC is a reasonable estimate of traffic from a city region, from an airport, on a certain route or by a certain airline. Using ASC over a period of time thus becomes a means to describe change in the supply of aviation. ${ }^{1}$

Analysing available seat capacity is an established method ( Burghouwt \& Hakfoort 2001; Bowen 2010; Transportstyrelsen 2012). The method does however have some deficiencies. Firstly, it does not record statistics; it is the planned supply of connections that is recorded. There are changes in traffic not shown in this material. Secondly, there are shortcomings in how some airlines report data, which sometimes forces one to double check with other sources. But, these kinds of mistakes are very uncommon. The material is in fact very robust; errors are fewer than in most quantitative material.

\footnotetext{
${ }^{1}$ ASC should not be confused with ASK, available seat kilometres, in which the number of available seats are multiplied with the number of kilometres flown. This figure is very interesting in estimating the environmental impact of a certain connection.
} 


\section{Analysis}

In the analysis, three interrelated perspectives have been identified, which are used to explain interrelationships between geopolitical development and the development of mobility patterns. Firstly, the role of macro-economic development, primarily international business cycles and their localized outcomes, is discussed. Secondly, changes in the orientation of international air connections are related to changes in regional systems. Lastly, the impact of economic deregulation after the enlargement of the European Union and the following development of new business models in aviation is discussed, both as a result of institutional change and as a driving force of increasing internationalization. Together, these perspectives point at the importance of institutional development as an explanation for changes in regional structures, bordering processes and in the formation of regional systems.

\section{Macro-economic development}

Since the transition to market economy, the former socialist economies have been sensitive to the volatility of business cycles and other external change. Small economies going through major structural change are particularly vulnerable to external factors (Paldam 2002). Business cycles are reflected in traffic data. During the first half of the 1990 's, the former socialist countries faced great economic difficulties. In that period, air traffic from the Baltic States generally grew at around 10 percent annually. However, the total amount of traffic was still small until 2004. At Minsk and Kaliningrad, traffic numbers were growing at an even slower pace in the 1990's (Erlandsson 1998; Nilsson 2003). Despite low traffic volumes, the internationalisation process that commenced in 1991 represents a turning point in the development of mobility in the area. Conditions for trade and other economic relations improved; barriers to travel were gradually reduced (Nilsson 2000). This would probably been more clearly reflected in travel numbers, had not the economic situation been so difficult in the 1990's. As the economies recovered air traffic followed, but when the Baltic States went through another economic crisis towards the turn of the millennium, it is also clearly visible in decreasing traffic intensity.

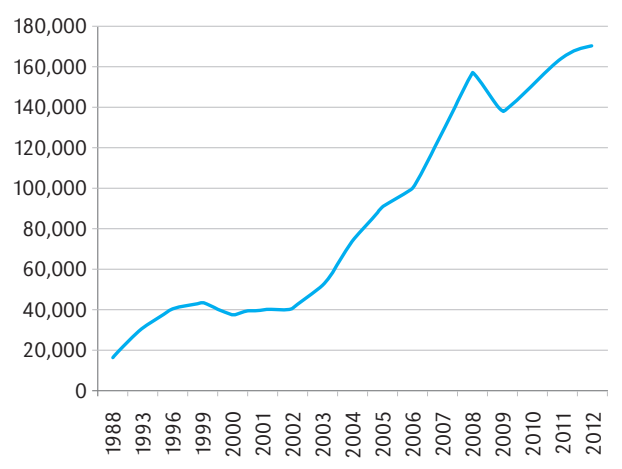

Figure 1. Available Seat Capacity, in 1000 's, per week 1988-2012, all examined airports together Source: OAG World Airways Guides. ${ }^{2}$

After the crisis around 2000, the Baltic States' economies started to grow again; in 2000-2007, the average growth rate was $8.2 \%$ a year. Despite considerable structural improvement the Baltic States were however still vulnerable to external shock. In 2009, following the international financial crisis, GDP shrunk by $13.9 \%$ in Estonia, $14.7 \%$ in Lithuania, and $18 \%$ in Latvia. By 2011, all three countries had recovered economically (Eurostat 2014; cf. Grigorev \& Abigalov 2011). As seen in Figure 1, all these macro events are reflected in traffic data: From 2000 to 2012, air traffic from the Baltic States ' airports grew on average $14.9 \%$ a year. In comparison, the global growth rate was $4.8 \%$ a year between 2000 and 2011 (Trafikanalys 2013). After the financial crisis and the following downturn in traffic, air traffic has returned to somewhat more moderate growth rates; there have so far not come any new significant factors

\footnotetext{
${ }^{2}$ Data from earlier periods (1988, 1993, 1996 and 1999) used in this paper are taken from Nilsson (2003). There are minor dissimilarities in recording methods.
} 
influencing traffic on the macro level. Over the period as a whole, the high growth of air traffic is a strong material evidence of the internationalisation process taking place in the Baltic States, and the countries' transition to capitalist market economies.

Kaliningrad has a history of moderate traffic mainly directed to Moscow, St Petersburg and other cities in the former Soviet Union. Since 2000 traffic has grown at exceptional rates at two occasions. The first one is in 2003 and 2004; which coincides with the expansion of the EU making connections over land more difficult. The second is related to the Kaliningrad based carrier KD Avia, which started to expand its operations rapidly in 20062007. Their aim was to establish Kaliningrad as a hub for traffic between Western Europe and the former Soviet Union. In the financial crisis the strategy failed and the airline went bankrupt (Aviation Week 2009). After the speculative expansion in 2007-09, traffic from Kaliningrad returned to its previous pattern. The routes to Moscow and St Petersburg dominate traffic ( $85 \%$ of ASC). There are few connections to Western Europe; in 2012 four weekly connections to Berlin and Copenhagen respectively, together less than $3 \%$ of traffic. The main difference to the early 2000 's is the total amount of traffic, which has increased considerably over the period despite the downturn after 2009. The general development is likely to reflect the positive economic development in Russia from the late 1990's onwards.

It is interesting to compare the dynamic developments in the Baltic States and Kaliningrad with the relative stability in Belarus. Air travel from Belarus is very limited; what stands out the most are the total numbers. 20,000 passengers a week (2012) from the only international airport of a country with 10 million inhabitants is a very low number. The number of incoming tourists to Belarus is very small; 119,000 overnight visitors were recorded in 2010 , which represents $3.7 \%$ of the corresponding number for Estonia (UNWTO 2012). Thus, air traffic at Minsk mainly cater for the domestic demand. This said; traffic from Minsk shows a remarkably stable development, with a fourfold increase between 2000 and 2013, and without being visibly affected by the financial crisis. This reflects a period of remarkably high and stable economic growth in Belarus from 1996 to 2014. The growth pattern resembles Russia's but with less fluctuation (Dobrinsky et al. 2016).

Ever since the geo-political transition in 1991 there has been significant growth in trans-border aviation. This reflects the fact that international borders have become more transparent, i.e. that a de-bordering process has been taking place in the region. The variations in the growth of aviation can partly be explained by fluctuations in business cycles. This is most visible in the case of the Baltic States, being small and open economies more vulnerable to external change than Russia and Belarus. However, the development of political and economic institutions is also influencing cross-border interaction, for example in aviation. Following institutional theory, institutions may have direct or indirect impact on economic growth, but they are also vital for the development of formal and in-formal cross-border networks. These are particularly interesting when it comes to understanding regionalisation and changes in regional systems.

\section{Development of institutions and regional systems}

Immediately after 1991 we saw a sharp increase in the number of international connections together with a radical shift in the direction of connections from the East to the West. From a situation where almost $100 \%$ of traffic from the Baltic States and Belarus went through Moscow in 1988, traffic to Western Europe became more significant. Traffic to the former Soviet Union decreased, both relatively and in absolute numbers. In the first half of the 2000 's, only between 5 and $10 \%$ of traffic from the Baltic States' capitals was directed to the former Soviet Union. It is a clear indication that the Baltic States changed its place in the regional system after the fall of the Soviet Union. Instead of being parts of the Soviet 
regional system, centred on Moscow, their orientations shifted westwards.

When the integration process in the Baltic Sea Region gained pace after 1991, air traffic between the Baltic States and the Nordic countries grew very fast. In 2001, $67 \%$ of traffic from Estonia was directed to the Nordic countries, from Latvia 56\%, and from Lithuania $46 \%$. This coincided with considerable flows of trade and investments between the Baltic States and the Nordic countries (Nilsson 2003). In the 1990 's the Baltic States formed close political and economic ties with the Nordic countries (Jauhiainen 2000). It is fair to say that the Baltic States' internationalisation process to a large extent went through the Nordic countries. There were thus evidence for a Nordic-Baltic regionalisation process taking place in the late 1990's and early 2000 's. Political cooperation was followed by developments of material infrastructure and increasing flows of trade, travel and investments. The enlargement of the European Union would soon change this pattern.

We can see dramatic increase in air traffic when Estonia, Latvia and Lithuania became members of the European Union in 2004. Between 2003 and 2005, the number of direct connections from the Baltic capitals to major
European cities increased by $65 \%$. In the process the relative orientation of air traffic changed, the dependence of connections to the Nordic countries decreased. The proportion of point-to-point connections grew as traffic to the hubs in Stockholm and Copenhagen remained constant, their relative importance decreased from 38\% in 2000 to $17 \%$ in 2005 (cf. Nilsson 2003; Wichmann Matthiessen 2004). Transit through these airports cities has declined. The Baltic States air traffic networks started to differ much more from one another than they did in the 1990 's. Traffic from Tallinn reflects Estonia's close relations to the Nordic economic sphere; in 2012, 30\% of Estonia's foreign trade was directed to Finland and Sweden, the country's two most important trading partners (Statistics Estonia 2014). As much as $36 \%$ of the traffic from Tallinn went to Nordic countries in 2012. Traffic to Helsinki, Copenhagen and Stockholm is still important in absolute numbers but is decreasing in relative terms.

As seen in Table 1, traffic from Riga started to grow exceptionally fast around 2004. The number of connections has increased along with the growth in passenger numbers, from 16 in 2000 to 59 in 2012. One effect of the rising number of connections is that the

Table 1. Available Seat Capacity, in 1000's seat/week 2000-2012, all examined airports

\begin{tabular}{|c|c|c|c|c|c|c|c|}
\hline Year & Tallinn & Riga & Klaipeda & Kaunas & Vilnius & Kaliningrad & Minsk \\
\hline 2000 & 10.0 & 10.5 & 0.7 & 0.5 & 9.2 & 1.2 & 5.3 \\
2001 & 11.1 & 10.6 & 0.7 & 0.3 & 10.1 & 1.8 & 6.0 \\
2002 & 10.4 & 9.9 & 0.9 & 0.4 & 10.4 & 3.3 & 5.8 \\
2003 & 12.6 & 10.4 & 1.6 & 0.6 & 12.4 & 8.6 & 6.1 \\
2004 & 17.0 & 20.6 & 1.7 & 0.6 & 17.5 & 9.6 & 8.0 \\
2005 & 21.5 & 32.6 & 2.3 & 1.6 & 15.9 & 10.4 & 7.2 \\
2006 & 20.5 & 36.2 & 2.2 & 3.3 & 18.2 & 10.9 & 7.8 \\
2007 & 24.4 & 45.7 & 1.4 & 4.3 & 21.3 & 22.0 & 9.5 \\
2008 & 25.3 & 59.3 & 1.1 & 5.1 & 27.5 & 26.6 & 12.6 \\
2009 & 18.3 & 61.0 & 1.8 & 5.8 & 14.6 & 21.7 & 14.1 \\
2010 & 20.5 & 70.4 & 1.3 & 11.6 & 16.9 & 12.7 & 15.5 \\
2011 & 27.8 & 65.8 & 1.4 & 11.3 & 22.4 & 15.5 & 20.2 \\
2012 & 31.8 & 62.4 & 1.8 & 10.4 & 28.0 & 15.3 & 20.5 \\
\hline
\end{tabular}

Source: OAG World Airways Guides 
dependence on the nodes in Copenhagen and Stockholm went down from $47 \%$ in 2000 to $8 \%$ in 2012 . The most important reason for the dramatic increase of traffic at Riga is the fact that the Latvian airline Air Baltic uses Riga Airport as its base. Air Baltic aimed at establishing Riga as a regional hub, directing traffic between Western and Eastern Europe through Riga (Flick 2007). Initially the strategy was successful; later most routes east of Moscow were closed. To compensate, Air Baltic increased its connections to minor airports in Norway and Finland at the same time as the number of transit options at Riga from other Baltic cities was expanded. The city's position in Baltic aviation was further strengthened by the presence of other low-cost carriers, most importantly Ryanair with connections to 13 European cities in 2012.

Until 2008, traffic from the Lithuanian airports showed steady but not dramatic growth. Thereafter, traffic from Vilnius decreased dramatically as a result of the financial crisis and the bankruptcy of the national flag carrier in 2009 (Baltic Times 2010). It took Vilnius airport three years to recover. In the meantime, low-cost traffic from Kaunas took over the international traffic. Connections to major cities in Western Europe dominate traffic from all three Lithuanian airports in 2012; only $7 \%$ of traffic was directed to Russia and the Ukraine. Despite large differences in absolute growth, aviation data show large similarities between Latvia and Lithuania in their respective orientations of traffic. The connections to the Baltic Sea Region are still important but are getting less significant in relative terms. In 2012, only $12 \%$ of traffic from Vilnius was directed to Nordic airports. Instead, most of the air traffic from Latvia and Lithuania is directed to major cities in Western Europe, like London, Frankfurt and Milan. Seen in terms of aviation, integration is less related to geographical proximity and more on networks within a larger regional system.

There are services from Minsk to most parts of Europe, the former Soviet Union and the Middle East. Over the years, the number of connections has remained stable, only a few have been added or closed down. Its eastbound connections, to Turkey, Central Asia and the Caucasian republics, have shown the largest increase since 2005. Traffic to Moscow still amounts to $36 \%$ of the total. The share of air traffic from Minsk bound for the European Union reached $60 \%$ in 2005 , but has since then gone down to $32 \%$ in 2012 . This relative re-orientation occurred at the same time as trade relations with Russia and Kazakhstan were invigorated by the Euroasian Customs Union, which has become more relevant since its formation in 2010 (Dobrinsky et al. 2016). This might explain the relative decrease in air traffic to Western Europe; which however represent an absolute increase of $52 \%$. This indicates that the relative changes in the direction of connections discussed here takes place within a context of increasing internationalisation. Despite evidence of re-bordering, e.g. in the relations between Russia, Belarus and the EU; traffic and trade is still on a higher level than at any previous point in time.

The volatile situation in the aviation market is to a large extent described as an indirect result of changes in institutional frameworks, most importantly as a result of the European Union enlargement. However, the impact of institutional development goes further than this. The European Union is in itself an important generator of travel, not only because politicians and civil servants travel to Brussels on a regular basis but also as a result of civil networks created within the context of the Union. Between 2002 and 2005, traffic from the Baltic states to major cities in Western Europe increased by $340 \%$. The importance of the European Union is also evident when comparing the development of international traffic in the Baltic States with that of Kaliningrad and Belarus. By its stimulus to growth in mobility, the integration process in the European Union acts to enhance re-bordering processes between its member states and their Eastern neighbours. Institutional change taking place in the European Union may also have significant in-direct impact on regionalisation, not the least through political measures targeting transports and 
infrastructure. As shown below, de-regulation of aviation opening up for low-cost aviation is clearly a case in point.

\section{Low-cost aviation and the new European mobility}

The increase in traffic after 2005 is partly related to changes in the aviation market. Prior to 2004 more than $90 \%$ of traffic was run by traditional national airlines, the remaining part by small regional carriers. The growth immediately following the enlargement of the European Union was mainly driven by these traditional carriers. However, following the EU membership, aviation in East-Central Europe was de-regulated. This allowed low-cost carriers such as Ryanair, Air Baltic and Norwegian to establish their business model in the new member states. The second wave of traffic growth, in 2005-2008, was mainly driven by low-cost carriers (Nilsson 2009; cf. Gross \& Lück 2013). The development of low-cost aviation had an almost radical impact in parts of the Baltic Sea Region.

Riga's importance as low-cost hub was mentioned above. Kaunas is maybe an even better example of how low-cost aviation influence regional aviation, as low-cost carriers favour secondary airport for economic reasons. The strong development at Kaunas airport was a result of Ryanair's presence; it totally dominated traffic from Kaunas airport between 2005 and 2010. In 2012, Ryanair operated 16 connections to destinations all over Europe, seven of which to the UK and Ireland; London alone made up 29\% of traffic from Kaunas. Competition from secondary airports forced airport authorities in the major cities to invite low-cost carriers as well. Consequently, low-cost carriers have increased their share of traffic from Vilnius and Tallinn too. So far, no low-cost carriers have moved into the Belarus market. The national carrier, Belavia, is the dominant actor in Minsk, often in 'classic' dual arrangements with other flag carriers (Doganis 2006). Low-cost aviation has clearly strengthened the internationalisation process in the Baltic States. On the other hand, the absence of institutional change in Russia and Belarus means that the differences between these countries and the rest of Europe become more visible. It could even be viewed as being evidence of a partial re-bordering process.

The high growth in air traffic from the three Baltic States could be assumed to be driven by corresponding growth in incoming tourism. Foreign tourism to the eastern part of the Baltic Sea Region (with the exception of Belarus and the Kaliningrad region) increased significantly from the early 1990 's until around 2005 following improved connections and fewer barriers to personal travel. Since 2005, tourism growth has been modest (Statistics Lithuania 2013; Visit Estonia 2013; Latvijas statistika 2014). The highly dynamic development of air travel compared to the relatively slow development of incoming tourism in the Baltic States suggests that a considerable part of low-cost traffic consists of people from the Baltic States travelling to Western Europe. Furthermore, there is only limited resemblance between data on the distribution of incoming tourists and the pattern of low-cost connections. The increase in low-cost traffic is therefore likely connected to the freedom of labour movement within the European inner market (cf. Dobruszkes 2009).

The networks developed by low-cost carriers in the Baltic States show a clear orientation towards Western Europe; in 2012, 42\% of low-cost traffic was directed to Great Britain and Ireland, 16\% to Germany and 22\% to the Nordic Countries. There are striking similarities between data on low-cost connections and data on migration from the Baltic States. After the EU-memberships and the extension of the Schengen zone, migration from the Baltic countries grew rapidly; figures are unreliable but suggest that as much as " $10 \%$ of economically active Lithuanians moved (at least temporarily) to the UK and Ireland during 2004-2008" (Hazans \& Philips 2010: 261). Latvian emigration is similar to the Lithuanian, reaching a peak of almost 40,000 people (1.8\% of the country's population) in 2009 (Latvijas statistika 2014). Estonian work migration has generally been at a lower level and 
more directed towards the Nordic countries. Hazans and Philips (2010: 299) conclude that "[p]ost-accession migrant flows from the Baltics were predominantly temporary and circulatory". (It should be noted that these flows are highly asymmetric and the volumes represent a considerable net loss for the Baltic States.) In relation to this study, temporality and circulation means increasing demand for travel. It is also likely that low-cost opportunities are a driving force behind these kinds of working mobility; it is cheap, time-efficient, and simple. Low-cost aviation has become a vital force in functionally integrating the European labour market. The amount of air traffic is thus an indication of the extent to which people from the Baltic States are travelling to work in Western Europe, or of the not so permanent character of contemporary migration. Clearly low-cost carriers have created their own markets by attracting new segments to aviation using low-price strategies. The emerging mobility patterns, largely created by low-cost aviation, could be viewed as un-intentional results of a marketization policy, mainly aimed at increasing competition in aviation. Nevertheless, this particular business model has become an important instrument for integrating the eastern and western parts of the European Union by functionally strengthening the common labour market.

\section{Concluding discussion}

The present study shows that most kinds of cross-border interaction in the Baltic Sea Region have increased during the studied period, including international aviation. The process of internationalisation could thus be viewed as the most fundamental one. All parts of the region are today connected to global networks. The process has been very fast and radical in the Baltic States whereas progress have been slower in the cases of Belarus and Kaliningrad. Nevertheless, international air traffic from both Minsk and Kaliningrad has increased significantly. Despite some contradictions and uncertainties, processes of de-bordering have evidently been more important than those of re-bordering. Most barriers to cross-border interaction have been reduced and the number of people travelling internationally has multiplied. All parts of the Baltic Sea Region are today a lot more open and international compared to the situation in 1991.

If we look more specifically at the regionalisation process in the Baltic Sea Region, it is possible to see that it has developed in stages. Prior to 1991, the Eastern parts of the Baltics were of course fully integrated in the Soviet system. After the geo-political transition in 1991, the three Baltic States soon developed close relations to the Nordic countries. This was clearly visible in air traffic, as well as in politics, trade and in the early presence of Nordic companies (Nilsson 2003; Vanags 2011). Connecting the newly independent nations to the established Nordic regional system may in hindsight be viewed as a first stepping stone in their internationalisation process.

After the enlargement of the European Union in 2004, all the three Baltic States have deepened their contacts with Western Europe. The amount of air traffic and the number of connections to Western Europe increased very rapidly. In the cases of Latvia and Lithuania, the relative importance of their connections to the Nordic countries has decreased. They are now to be regarded more as parts of a European regional system than simply as parts of the Baltic Sea Region. Their regionalization processes have become less spatially fixed, borders have become de-centred. The process could be described as leapfrogging, bypassing neighbouring areas, and going straight to the political and economic centres of Western Europe. Physical proximity between actors is thus not necessarily as important as it used to be, proximity in networks seems to be more important. The institutional framework of the European Union has been a necessary prerequisite for this process to develop, directly through the reduction of barriers to interaction and in-directly through changes in governance. De-regulation of transportation, allowing for the development of low-cost aviation, is an important example of the latter. 
The position of Estonia is different from that of its Baltic neighbours. Estonia has strengthened its contacts to Western Europe, but retained its strong connections to the Nordic countries, in particular Finland and Sweden. Estonia could today be viewed as functionally integrated into the Nordic countries, not only in terms of mobility and economic relations but also culturally and socially. Travel and migration patterns support this view. In this respect the present situation to some extent resembles the functional systems drawn up by Edgar Kant $(1935 a, b)$ in the interwar period. The process could be interpreted as an example of cross-border regionalization. The materialities of integration between Estonia and its Nordic neighbours are present. However, building on Paasi's (1986) model for institutionalization of regions, the regionalization process is far from complete. There are plenty of evidence for the development of institutions, but the other stages in Paasi's model seem to be lacking.

Despite increasing levels of internationalization in general, the processes described above have little correspondence in the cases of Kaliningrad and Belarus. Patterns of aviation show strong connections to Russia and other parts the former Soviet Union, with regular but not very frequent connections to Western Europe and very low levels of traffic to other parts of the Baltic Sea Region. There are even signs of a reversed process in some areas since the Schengen Area was enlarged in 2007. However, the evidence of this mainly refer to ground transport (Komornicki 2010) and can't be seen in the aviation material. But, the fact that Belarus and Russia stay outside the European integration process means that the situation could be viewed as a re-bordering process - relatively speaking.

To conclude: After the geo-political transition in 1989-91, the Baltic Sea Region became an important arena for political cooperation. The regionalization process was at the beginning mainly shaped politically. The political processes also encouraged the development of functional integration, i.e. of trade, investments, traffic and other forms of exchange.
However, this study suggests that the forces of European integration and internationalization have become stronger during the last fifteen years, in particular after the enlargement of the European Union. Today, both political and functional forces seem to point at the same direction. If the Baltic Sea Region is viewed as one single region, there is little evidence of functional regional integration. Internal ties are not stronger than external connections, the necessary materialities of integration seem to be less well developed. Instead the Baltic Sea Region could be interpreted as belonging to two different larger systems: Western Europe (mainly the European Union) characterized by de-bordering, and a territorial system in Eastern Europe with Russia as the dominant element. In this context, the emerging cross-border region including Estonia, Finland and Sweden could be seen as a sub-system within Western Europe. Another way of putting it is that emerging processes of de-territorialisation in the European Union contrasts with prevailing national territorialities in the Euro-Asian sphere.

\section{Acknowledgements}

The author wishes to thank Richard Ek for valuable comments on an earlier version of this paper, and the two anonymous reviewers for their constructive comments.

Editors' note:

Unless otherwise stated, the sources of tables and figures are the authors', on the basis of their own research. 


\section{References}

AgneW J., 2008. Borders on the mind: Re-framing border thinking. Ethics and Global Politics, vol. 1, no. 4, pp. 175-191.

Anderson J., O' Dowd L., 1999. Borders, border regions, and territoriality: Contradictory meanings, changing significance. Regional Studies, vol. 33, no. 7, pp. 593-604.

Andreff M., AndrefF W., 1995. Economic disintegration in Eastern Europe: Towards a new integration [in:] B. Dallago, G. Pegorotti (eds.), Integration and disintegration in European economies, Aldershot: Dartmouth Publ.

AviATION WeEK, 8.9.2009. https://www.aviationweek.com [22 March 2011].

BAliBAR E., 2009. Europe as borderland. Environment and Planning D: Society and Space, vol. 27, no. 2, pp. 190-215.

BALtiC TIMES, 11.11.2010. http://www.baltictimes. com [22 March 2011].

BIALASIEWICZ L. (ed.), 2011. Europe in the World. EU geopolitics and the making of European space. Farnham: Ashgate.

Bialasiewicz L., Dahlman C., Apuzzo G.M., Ciută F., JONes A. Rumford C., Wodak R., ANDERSON J., INGRAM A., 2009. Interventions in the new political geographies of European 'neighbourhood'. Political Geography, vol. 28, no. 2, pp. 79-89.

Böhme H., Laaser C-F., Sichelschmidt H., SoltWeDEL R., 1998. Transports in the Baltic Sea region: Perspectives for the economies in transition. Kiel: Stockholm Chamber of Commerce.

Bowen J.T., 2010. A people set apart: The spatial development of airline business class services [in:] J.V. Beaverstock, B. Derudder, J.R. Faulconbridge, F.Witlox, (eds.), International business travel in the global economy, Farnham: Ashgate.

BRODIN A., 2000. Ports in transition in countries in transition: The changing situation for ports in Russia and the Baltic States in times of geopolitical and economical transition. Göteborg: Göteborg University: Department of Human and Economic Geography, Choros 2000:1.

BRUNeT-Jailly E., 2011. Special section: Borders, borderlands and theory: An introduction. Geopolitics, vol. 16, no. 1, pp. 1-6.

Burghouwt G., Hakfoort J., 2001. The evolution of the European aviation network, 1990-1998.
Journal of Air Transport Management, vol. 7, no. 5, pp. 311-318.

Christauskas J., Stanaitis J., 2008. Dynamics of passenger traffic flow at Vilnius, Riga, Tallinn and Krakow airports. Aviation, vol. 21, no. 1, pp. 28-32.

De Geer S., 1928. Das Geologische Fennoskandia und das Geographische Baltoskandia. Geografiska Annaler, vol. 10, pp. 119-139.

Derudder B., Devriendt L., van Nuffel N., WitLOX F., 2010. Geographies of business air travel in Europe [in:] J.V. Beaverstock, B. Derudder, J.R. Faulconbridge, F.Witlox (eds.), International business travel in the global economy, Farnham: Ashgate.

Derudder B., van Nuffel N., Witlox F., 2009. Connecting the world: Analyzing global city networks through airline flows [in:] S. Cwerner, S. Kesselring, J. Urry (eds.), Aeromobilities, London: Routledge.

Derudder B., Witlox F., 2008. Mapping world city networks through airline flows: Context, relevance and problems. Journal of Transport Geography, vol. 16, no. 5, pp. 305-312.

DEUTSCH K., 1953. Nationalism and social communication: An inquiry into the foundations of nationality. Cambridge: The MIT Press.

Dobrinsky R., Adarov A., Bornukova K., Havlik P., Hunya G., KRuk D., PIndyuk O., 2016. The Belarus economy: The challenges of stalled reform. Wiener Institut für Internationale Wirtschaftsvergleiche. Research Report No. 413.

DobrusZKes F., 2009. New Europe, new low-cost air services. Journal of Transport Geography, vol. 17, no. 6, pp. 423-432.

Doganis R., 2006. The airline business. Second edition, London: Routledge.

ELDEN S., 2011. Thinking territory historically. Geopolitics, vol. 15, no. 4, pp. 757-761.

ERLANDSSON U., 1998. Changes in air transportation concerning the Baltic states. Department of Social and Economic Geography. Lund University [unpublished paper].

Eurostat, 2014. Real GDP Growth Rates, http:// epp.eurostat.ec.europa.eu [18 March 2014].

Flıck B.M., 2007. Air Baltic: The dynamic market in the eastern part of the European Community [in:] S. Gross, A. Schröder (eds.), Handbook of lowcost airlines: Strategies, business processes and 
market environment. Berlin: Erich Schmidt Verlag, pp. 111-122.

Gerner K., Karlsson K-G., 2002. Nordens medelhav. Östersjöområdet som historia, myt och projekt. Stockholm: Natur och Kultur.

Grigorev L. Abigalov S., 2011. The Baltic countries: Looking for a way out of the crisis. Problems of Economic Transition, vol. 53, no. 12, pp. 20-42.

Grix J., Knowles V., 2002. The euroregion as a Social Capital Maximizer: The German-Polish Euroregion Pro-Europa Viadrina. Regional \& Federal Studies, vol. 12, no. 4, pp. 154-176.

Gross S., LüCK M., 2013. The low cost carrier worldwide. Abingdon: Ashgate.

HaZAns M., PHILIPS K., 2010. The post-enlargement migration experience in the Baltic labor markets [in:] M. Kahanec, K.F. Zimmermann (eds.), EU labor markets after post-enlargement migration, Berlin-Heidelberg: Springer Verlag, pp. 255-304.

Ioannides D., Nielsen P.A., Billing P., 2006. Transboundary collaboration in tourism: The case of the Bothnian Arc. Tourism Geographies, vol. 8, no. 2, pp. 122-42.

JAUHIAINEN J.S., 2000. Regional development and regional policy. European Union and the Baltic Sea Region. Turko: Turko University.

Jensen O.B., Richardson T., 2004. Making European space: Mobility, power and territorial identity. London: Routledge.

Joenniemi P., Sergunin A., 2011. When two aspire to be one: City-twinning in northern Europe. Journal of Borderlands Studies, vol. 26, no. 2, pp.231-242.

Jönsson C., TÄGIL S., TÖRnQVIST G., 2000. Organizing European space. London: Sage.

Kahila P., Roto J., Perjo L., Lange Scherbenske S., 2013. Cross-border labour mobility in the Central Baltic region. Nordregio Report 2013:2, Stockholm: Nordregio.

KANT E., 1935a. Bevölkerung und Lebensraum Estlands. Tartu: Postimees Trück.

Kant E., 1935b. Estland och Baltoskandia. Tartu: Särtryck ur Svio-Estonica.

KISIEL-ŁowczYC A.B., 2000. Bałtycka integracja ekonomiczna. Warszawa: Polskie Wydawnictwo Ekonomiczne.

KJellén R., 1899. Studier öfver Sveriges politiska gränser. Ymer, vol. 19, Stockholm.
KOMORNICKI T., 2010. Flows of persons and goods across the Polish segment of the outer boundary of the European Union - results of a research project [in:] T. Komornicki (ed.), European Union: External and internal borders, interactions and networks. Warszawa: Institute of Geography and Spatial Organization PAS.

Komornicki T., MiszcZUK A., 2010. Eastern Poland as the borderland of the European Union. Quaestiones Geographicae, vol. 29, no. 2, pp. 55-69.

KramsCh O.T., 2003. The temporalit(ies) of European cross-border governance: Euregions and the problem of sens. Journal of Borderland Studies, vol. 18 , no. 2, pp. 69-85.

KRÄTKE S., 1998. Regionale Integration oder fragmentierte Entwicklung? Die deutsch-polnische Grenzregion im Transformationsprozess. Zeitschrift für Wirtschaftsgeographie, vol. 42, no. 1, pp. 117-130.

LATVIJAS STATISTIKA, 2014. Centrālā statistikas pārvalde, Rīga, http://data.csb.gov.lv [27 March 2014].

LEFEBVRE H., 1991. The production of space. Oxford: Blackwell,

LEPIK K-L., 2009. Euroregions as mechanisms for strengthening cross-order cooperation in the Baltic Sea region. Trames, vol. 12, no. 3, pp. 265-284.

LIEVEN A., 1994. The Baltic revolution. Estonia, Latvia, Lithuania and the path to independence. New Haven: Yale University Press.

LösCH A., 1954. The economics of location. New Haven: Yale University Press.

LUndén T., Zalamans D., 2001. Local co-operation, ethnic diversity and state territoriality: The case of Haparanda and Tornio on the Sweden-Finland border. Geojournal, vol. 54, no. 1, pp. 33-42.

Mann M., 1993. Nation-states in Europe and other continents: Diversifying, developing, not dying. Daedalus, vol. 122, no. 3, pp. 115-140.

Niısson J.H., 2000. Utrikeshandeln i Östersjöområdet. Rapporter och Notiser, 159. Lund: Lund University. Institutionen för kulturgeografi och ekonomisk geografi.

NiısSON J.H., 2003. Östersjöområdet. Studier av interaktion och barriärer. Meddelanden från Lunds universitets geografiska institution, avhandlingar 152, Lund: Sisyfos förlag.

Nilsson J.H., 2009. Low-cost aviation [in:] S. Gössling, P. Upham (eds.), Climate change and aviation: Issues, challenges and solutions. London: Earthscan. 
NiLSSON J.H., 2015. Logistic revolutions and territorial change. Implications for the Baltic Sea region [in:] M. Grzechnik, H. Hurskainen (eds.), Beyond the Sea: Reviewing the manifold dimensions of water as barrier and bridge. Köln: Böhlau Verlag.

NiLsSON J.H., EskILSSON L., EK R., 2010. Creating cross-border destinations: Interreg programmes and regionalisation in the Baltic Sea area. Scandinavian Journal of Hospitality and Tourism, vol. 10, no. 2, pp. 153-172.

NORTH D., 1997. Institutionerna, tillväxten och välståndet. Stockholm: SNS förlag.

NorTH M., 2011. Geschichte der Ostsee: Handel und Kulturen. München: Verlag C.H. Beck.

NovaK P., 2011. The flexible territoriality of borders. Geopolitics, vol. 16, no. 4, pp. 741-767.

Nove A., 1992. An economic history of the USSR 1917-1991. Third edition. London: Penguin books.

OAG WorLd AIRWAYS GUIDES, 2000-2012. October issues.

O 'Tuathall G., 1998. Political geography III: Dealing with deterritorialization. Progress in Human Geography, vol. 22, no. 1, pp. 81-93.

PAASI A., 1986. The institutionalization of regions: A theoretical framework for understanding the emergence of regions and the constitution of regional identity. Fennia, vol. 164, no. 1.

PAASI A., 1996. Territories, boundaries and consciousness. Chichester: John Wiley \& Sons.

PALDAM M., 2002. Udviklingen i Rusland, Polen og Baltikum. Lys forude efter ændringen af det økonomiske system. Aarhus: Aarhus Universitetsforlag.

Parker N., Vaughan-Williams N., 2012. Critical border studies: Broadening and deepening the 'lines in the sand' agenda. Geopolitics, vol. 17, no. 4, pp. 727-733.

Ratzel F., 1923. Politische Geographie. München und Berlin: Verlag von R. Oldenburg,

SASSEN S., 2001. The global city: New York, London, Tokyo. Second edition. Princeton: Princeton University Press.

Schmitt P., Dubols A., 2008. Exploring the Baltic Sea region: On territorial capital and spatial integration. Stockholm: Nordregio.

SCHÖNWEITZ M., 2015. The Öresund region. Between utopia and reality [in:] M. Grzechnik, H. Hurskainen (eds.), Beyond the Sea: Reviewing the manifold dimensions of water as barrier and bridge. Köln: Böhlau Verlag, pp. 165-185.
ScoTT J.W., 2002. Baltic Sea regionalism, EU geopolitics and symbolic geographies of co-operation. Journal of Baltic Studies, vol. 33, no. 2, pp. 137-155.

ScotT J.W. (ed.), 2006. EU enlargement, region building and shifting borders of inclusion and exclusion. Farnham: Ashgate.

Scom J.W. (ed.), 2009a. Decoding new regionalism. Shifting socio-political contexts in Central Europe and Latin America. Farnham: Ashgate.

ScoT J.W. (ed.), 2009b. Bordering and ordering. The European neighbourhood: A critical perspective on EU territoriality and geopolitics. Trames, vol. 13 , no. 3, pp. 232-247.

SHAW D.J.B., 1999. Russia in the modern world: A new geography. Oxford: Blackwell.

Stålvant C-E., 1996. Actors around the Baltic Sea. Stockholm: Ministry for Foreign Affairs.

Statistics Estonia, 2014. Homepage, http://www. stat.ee [24 March 2014].

Statistics Lithuania, 2012. Statistical Yearbook of Lithuania 2012. http:// www.stat.gov.lt [25 March 2014].

Statistics Lithuania, 2013. Tourism in Lithuania 2012. http:// www.tourism.lt [27 March 2014].

TAYLOR P.J., 2004. World city network: A global urban analysis. London: Routledge.

Timothy D.J., SAarinen J., 2013. Cross-border cooperation and tourism in Europe [in:] C. Costa, E. Panyik, D. Buhalis D. (eds.), Trends in European tourism planning and organisation. Bristol: Channel View Publications.

TIMOthy D.J., SAARInen J., VIKen A., 2016. Editorial: Tourism issues and international borders in the Nordic Region. Scandinavian Journal of Hospitality and Tourism, vol. 16, suppl. 1, pp. 1-13.

TRAFIKANALYS, 2013. Luftfart 2012. http://www.trafa. se [18 March 2014].

TransPortSTYReLSEN, 2012. Planerat utbud i linjefart på svenska flygplatser. Oktober 2012. http:// www.transportstyrelsen.se/Global/Luftfart [25 March 2014].

UNWTO, 2012. Compendium of tourism statistics, data 2006-2010. http//:statistics.unwto.org [1 January2013].

VANAGS A., 2011. Economic integration and cohesion in the Baltic Sea region: A critical perspective from the Baltic States. Journal of Baltic Studies, vol. 42, no. 1, pp.91-102. 
Van Houtum H., 2000. III European perspectives on borderlands: An overview of European geographical research on borders and border regions. Journal of Borderland Studies, vol. 15, no. 1, pp. 57-83.

VAn Houtum H., Strüver A., 2002. Borders, strangers, doors and bridges. Space \& Polity, vol. 6, no. 2, pp. 141-146.

VASAB, 2010, Visions and strategies around the Baltic Sea 2010: Towards a framework for Spatial Development in the Baltic Sea Region. Karlskrona: Östersjöinstitutet.
VISIT EsTONIA, 2013. Tourism in Estonia 2013. http:// www.visitestonia.com [27 March 2014].

Wichmann Matthiessen C., 2004. International air traffic in the Baltic Sea Area: Hub-gateway status and prospects. Copenhagen in focus. Journal of Transport Geography, vol. 12, no. 3, pp. 197-206.

WięCKOWski M., CerlĆ D., 2016. Evolving tourism on the Baltic Sea coast: Perspectives on change on the Polish maritime borderland. Scandinavian Journal of Hospitality and Tourism, vol. 16, supp. 1, pp. 98-111. 